\title{
ARE FEMALES SUITABLE FOR POLICE DUTY?
}

\author{
${ }^{1,2}$ Bamboo Chen and ${ }^{2}$ Kuo-Wei Lin \\ ${ }^{1}$ First Company of Third Corps of Special Police Second Headquarters, \\ National Police Agency, Hsinchu, 30079, R.O.C. Taiwan \\ ${ }^{2}$ Department of Business Administration, Hsuan Chuang University, Hsinchu, 30092, R.O.C. Taiwan
}

Received 2013-04-21, Revised 2013-04-21; Accepted 2013-09-02

\begin{abstract}
Police work is a masculine job that needs physical strength and force and thus it is male-dominated working environment in Taiwan as in other countries. Under gender mainstreaming, Taiwan's society has gradually adhere the basic female human rights for equitable employment, with one example being that the Special Examination for Police canceled limits on quotas for females in order to offer equal opportunity employment. However, police often have to face uncertain dangerous situations and so under real operation conditions, if policewomen are exposed to dangerous situations, does this meet the requirements of "protection of maternity" in R.O.C. Constitution? This study finds that females generally perform better in the examination and hence the number of Taiwan's policewomen is set to significantly increase in the future. If this situation continues, then the fact that policewomen request equal employment on the one hand and request being protected on the other hand may affect the operations of police authorities. This study aims to explore: Whether or not women are suitable to engage in police work?
\end{abstract}

Keywords: Management Efficiency, Questionnaire Analysis, Gender Equality, Job analysis

\section{INTRODUCTION}

Police officers are called people's babysitters and their roles are not only to crack down on crime and show their masculine side, but also to protect and take care of innocent people, showing their soft and amicable side. Therefore, after the Nationalist government withdrew from mainland China and came to Taiwan in 1949, the Taiwan Police School began to recruit female graduates from junior high school. In order to enhance the quality of police, A-class Police Class opened up to graduates from senior high schools in 1969. Police College then allowed female students join in 1974, resulting in more and more females joining the force. With changes in Taiwan's society, female crimes increasing and the emergence of the sex industry and violence upon women and children, the police force is depending more and more on policewomen to handle police work.

In reviewing the development of policewomen, we see after the introduction of them into the force that their main responsibility is in responding to the demands from society and dealing with female crimes or crimes on Corresponding Author: Kuo-Wei Lin, Department of Business Administration, Hsuan Chuang University, Hsinchu, 30092, R.O.C. Taiwan women and children mess. After opening up the police force in Taiwan to females and through the requirement of gender equality, the police force has had to recruit new members through fair examinations, but the fact that female students have generally performed better than male students on the examination has resulted in recruiting an excessive number of females to take on police duties. However, the innate weakness of females compared to males often causes difficulties in assigning field duties by the police station. Therefore, the purpose of this study is to explore if females are indeed suitable for joining the police force.

This study begins by researching the problems that policewomen encounter in their daily work. It then proceeds by analyzing the advantages and disadvantages of policewomen. Finally, this study offers some recommendations.

\section{MATERIALS AND METHODS}

Literature review is to discuss problems encountered by policewomen in police organizations. 


\subsection{Unfairness of Promotions and Awards}

Like male colleagues, policewomen have to pass the tough Special Examination for Police and receive stringent education and training before becoming a qualified police officer. In masculine police organizations, policewomen are recognized only as nominally being a police officer, because police organizations are full of patriarchal control and thought processes that believe policewomen can only do office work without incurring any heavy responsibilities. Yeh (2004) pointed out that most police organizations have lower expectations for policewomen and do not give them too much or too heavy of a workload, leading to fewer opportunities for promotion. Such situations are not fair to policewomen who are seeking full-time careers in the police force. Therefore, if a policewoman wanted to be treated fairly, then she has to learn how to integrate herself into a male-dominated police culture, behave like her male colleagues and implement any work that a policeman normally does. Young (2006) argued that policewomen have to play down their female consciousness in the workplace, which is affirmed by achieving performances, inputting more energy and demonstrating their strong capability at work just like their male colleagues so as to break the predicament of gender inequalities.

\subsection{Role as a Spare Tire}

For a long time, females have played a role as a reserve and support force in the workplace. During World War I and World War II, males were sent off to battlefield and their jobs were taken over by females. After the wars' end, the males returned to the workplace and the females were again driven back to the family.

The work of policewomen is considered as not being important and only marginal. In fact, most responsibilities of policewomen are those that their male colleagues cannot do, such as body searches on female suspects, accompanying female victims who experienced sexual assault to assess injuries and writing up deposition. These demands upon policewomen are often ignored by police units, which neglect the values of the existence of policewomen. Chiang (1994) found that the police often assigned unimportant and marginal jobs, such as traffic control, ticketing and the protection of women and children, to policewomen for enforcement. However, can the police, which have a bounded duty for suppressing crimes and pacifying the good, really consider the above-mentioned jobs as being not important and only marginal? Moreover, can the police even consider those policewomen who silently put forth their efforts on those jobs as being just an invalid part of the police force and discriminate them in every possible way?

\subsection{Physiological Differences of Females}

In earlier times, there was a restriction on the recruitment of policewomen in Taiwan, but after women rights groups' vigorous efforts to fight for women's right to work, the Special Examination for Ordinary Police rescinded the policy of gender-based quota restrictions beginning in 2010. However, because females often achieve better results on the examinations, police organizations have recruited a lot more policewomen and assigned them to police stations. Due to receiving equal pay, policewomen have to conduct the same tasks as their male colleagues. Despite the fact that some policewomen are forced to adjust their work schedule for pregnancy, childbirth and physiological conditions, police stations have been unable to provide them with enough office work. Under such situations, many policewomen in police stations may work at night and rest during the day, when unexpected situations may happen that put them under great performance pressure. They suffer terribly due to physical and mental exhaustion, which prevents them from bringing their female advantages into full play in the police force.

\subsection{Threats Encountered in Enforcement}

The means of law enforcement by police include control, intervention, coercer and the handling of emergencies in which people instinctively give way to the public authority and enforcement by the police. However, Chiang (2007) argued that male domination over the female exists in Asian societies and people intuitively think policemen, not policewomen, are the police and so they psychologically fear only law enforcement by policemen. People may neglect or even challenge such enforcement by policewomen. When facing crimes, policewomen sometimes have to face resistance and challenges from criminals, which may increase the difficulties in enforcement and pose a threat to the public authority.

\subsection{The Puzzle over Policewomen's Beauty}

The general public usually does not pay attention to the attitude and specialty duties of policewomen on duty, but often find faults with their height, face and body appearance. Chiang (2007) argued that the general public expects a policewoman to be a charming, graceful girl and quiet like a sleeping child on the one hand, but able 
to move fast like a rabbit and be bold like a man on the other hand if necessary. Such expectations in fact have materialized policewomen. Even in promotional materials, police authorities emphasize that there are many beautiful policewomen, but publicize less their professional skills and contributions. This also falls into the category of materializing policewomen. It is no wonder that some car, truck, or motorcycle drivers who have violated traffic rules said they were happy to accept tickets from beautiful policewomen. However, the situation goes contrary to the purpose of recruiting policewomen: to keep the peace.

\subsection{Advantages of Policewomen in Police Work: Improving the Relationship with the Public}

The natural characteristic of a policewoman is being more soft and patient, whereas a policeman is prone to using forceful intervention, which usually causes violent conflicts with the people. If policewomen can give their male colleagues advice in time, softly persuade the crowd and provide patient explanations, then conflicts should be resolved in a more peaceful manner. Indeed, policewomen can play the role as a buffer of emotions, smooth the enforcement of duties and reduce arguments and public discontent.

\subsection{Increase the Solving of Criminal Cases}

In trying to solve criminal cases, the police force sometimes needs policewomen to help achieve the task through disguises. For example, policewomen disguise themselves as ordinary housewives in order to penetrate illegal casinos, dress as modern girls to raid a home sex home party, act as a girl walking alone to lure robbers and play as lovers to bring robbers to justice. These police jobs cannot be done by policemen alone or by women who have not received any training.

\subsection{Good at Woman and Child Cases}

Chang (1999) stressed that policewomen are able to better deal with sexual assault cases than their male colleagues, policewomen are more effective in dealing with family crisis cases and policewomen also enjoy higher success rates than their male colleagues in dealing with juvenile cases. Yeh (2003) found that policewomen are superior to policemen in dealing with domestic violence cases. Due to female empathy, policewomen find it easier to get started in dealing with woman and child cases. Because most victims of sexual assault or sexual harassment are women and female victims usually prefer to discuss their cases with policewomen, the police force naturally needs policewomen to deal with woman and child cases.

\subsection{Enforce Specific Jobs}

Article 123 of the Code of Criminal Procedure provides that "the search of a woman's body shall be conducted by a woman". Therefore, according to the law, policewomen have to enforce security checks of female passengers at airports or be there when arresting woman in flagrante delicto, wanted criminals and female suspects.

\subsection{Disadvantages of Policewomen in Police Work: A Policewoman Should Not Be on Duty Alone}

The duties of a police station include inspection of service areas, patrolling, checking, keeping guard, on duty and standby. The work emphasizes offensive and proactive service. However, most policewomen are not strong enough to handle criminal cases alone due to the consideration of security and thus station chiefs usually arrange a policewoman to be on duty with a male colleague. However, when manpower is not enough, it is a difficult decision to send policewoman to handles cases under risk of their personal safety.

\subsection{Policewomen Have Too Many Personal Problems}

Due to personal or family factors, the problems a policewoman face may be more than the problems that their male colleagues have. Examples include physiological leave during a menstrual period, work leave during the early period of pregnancy, 14-42 days of abortion leave, 42 days childbirth leave and parental leave for taking care of a baby. These are legal leaves based on humanistic concerns, but if a policewoman wants to ask for a longer leave, then the scheduling of word duties is inevitably affected. If three policewomen ask for leaves due to physiological reasons, a police station could find it difficult to operate effectively.

\subsection{Affection Problems between Policewomen and Policeman}

People are creatures of affection. Male and female police colleagues must get along and work together at least $12 \mathrm{~h}$ a day in a police station. Such long periods of contact and the sharing of personal issues and woes may cause feelings of affection to arise between colleagues of the opposite sex. If both are unmarried, then there 
are fewer problems encountered, but if one is married or both are married, then such a circumstance may cause bigger problems that a police organization must pay attention to.

\subsection{Haggles over Work}

Under a certain prescribed number, recruiting too many females to work in police stations will crowd out male police officers. In the past, police stations almost had zero police officers. If a policewoman joins the force, then the other male colleagues will protect her as an expression of chivalry and never haggle over the work responsibility of their female co-workers. However, the numbers of policewomen are on the rise. If a police station arranges policewomen to be on office duty or on daily duty, then their male colleagues have to increase their own field services, night duty and midnight duty, which could turn males around and hence result in internal disputes.

\section{RESULTS AND DISCUSSION}

\subsection{Formulate the Proportion of Males and Females According to Actual Needs of the Police Organizations}

The data on the gender of suspects in 2001-2011 published by the National Police Agency, Ministry of Interior (Table 1), show that the proportion of male and female suspects is from $4.43: 1$ to 6.14 :1, with an average of 5.06:1. Hence, the needs for male police are far greater than that for female police. However, since 2010 after rescinding the limits on the female recruitment proportion from the Special Examination for Police, the ratio of male to female police officers stands now at $56: 44$, which does not match the actual needs of police organizations. Therefore, this study recommends that the recruitment proportion of male and female police from the Special Examination for Police be adjusted to 5:1, which is more in line with the proportion of male and female criminal suspects.

\subsection{Specific Work by Gender}

Policewomen and policemen should engage in the same work, Lin (2013) argued that treating different things with different principles would result in real justice. She stressed that women have physiological menstrual periods, pregnancies and lactations that men will never encounter in their lives and thus different things should be treated in different ways. Hence, policewomen should be given differential treatment as a way of showing support for them in the police force. It is not necessary for policewomen to do frontline work in police stations like policemen do. There are many job duties, such as women and children affairs, security, traffic, foreign affairs, administration, forensics, information and household registration that provide policewomen with regular rotations that can increase their personal job experiences and prevent them from getting tired of police work services.

This study interviewed 23 policewomen and 19 policemen. From the findings, $78.26 \%$ of policewomen and $68.42 \%$ of policemen do not favor rescinding the limits on the policewomen recruitment proportion. Both sexes do recognize policewomen's contributions to police organizations and believe the women and children teams as well as traffic teams are more suitable for policewomen, because they are more thoughtful and caring than policemen naturally are and the common people can feel the high-quality of police services. The respondents also note that if too many policewomen work in a police station, then the station may not operate smoothly.

Table 1. 2001-2011 Data of gender among crime suspects in Taiwan

\begin{tabular}{|c|c|c|c|c|}
\hline Year & $\begin{array}{l}\text { No. of male } \\
\text { suspects }\end{array}$ & $\begin{array}{l}\text { No. of female } \\
\text { suspects }\end{array}$ & $\begin{array}{l}\text { Total } \\
\text { suspects }\end{array}$ & $\begin{array}{l}\text { Proportion of male } \\
\text { and female suspects }\end{array}$ \\
\hline 2001 & 155,226 & 25,301 & 180,527 & 6.14 \\
\hline 2002 & 155,666 & 30,085 & 185,751 & 5.17 \\
\hline 2003 & 134,394 & 24,293 & 158,687 & 5.53 \\
\hline 2004 & 150,376 & 26,599 & 176,975 & 5.65 \\
\hline 2005 & 173,286 & 34,139 & 207,425 & 5.08 \\
\hline 2006 & 189,495 & 39,698 & 229,193 & 4.77 \\
\hline 2007 & 221,006 & 44,854 & 265,860 & 4.93 \\
\hline 2008 & 225,335 & 45,851 & 271,186 & 4.91 \\
\hline 2009 & 214,583 & 47,390 & 261,973 & 4.53 \\
\hline 2010 & 219,709 & 49,631 & 269,340 & 4.43 \\
\hline 2011 & 212,981 & 47,375 & 260,356 & 4.50 \\
\hline
\end{tabular}




\subsection{Different Pays for Different Works}

Male police officers do not favor the implementation of gender mainstreaming. According to a survey conducted by this study, $63.16 \%$ of policemen said they did not feel there is equal gender treatment in the police force. Instead, they believe that the authorities give more protection to policewomen, because the males complained that under the same salary, policewomen are always given easier task jobs. Mutual accusations and distrust are not good things for a team. The question for policemen is: with the same salary, ask male police officers to do the work why policewomen do not like to do? If the compensation system is adjusted so that (1) those who are on night duty and midnight duty are given double wages, (2) different pay scales are initiated for different jobs and (3) hard-working police officers can obtain more compensation, then this would be more in line with the purpose of gender mainstreaming and caring about both policemen and policewomen.

\subsection{Promotions and Promotion Vision}

There is no specific gender limits in the police personnel promotion system, but in actuality the system is subject to artificial control. Therefore, police organizations should clearly plan a vision for job promotions and help both policemen and policewomen to achieve such goals. The authorities should clarify what job positions one should experience and what training one should receive before he or she is promoted. Moreover, unfair appointments and promotions caused by gender differences should be eliminated in order to have a more transparent and open personnel system.

\section{CONCLUSION}

Following the above discussions concerning the question of whether females are suitable for police duty, this study comes to the conclusion that police organizations do in fact need females interested in a police career, but should limit the proportions of policewomen recruitment according to actual needs. The most important thing is that the police authorities should follow the recommendation of Sandel (2011) and the advocacy of Aristotle-in other words, who gets best flute? Answer: the best flute player. Police organizations must give the most talented people the opportunity to best use their abilities and put the right person in the right position without considering the gender of the police officer. Weng (2007) also found in a survey that police works are almost all-inclusive, in which much of them are of a different nature that is better suitable for different persons to do. Thus, the suitability of talent and personality, not gender, should be considered when assigning police work. Police leaders should open their minds and give aspiring policewomen the opportunity to bring forth their specialties into full play during their police career.

\section{REFERENCES}

Chang, W., 1999. The voice of policewomen-Gender obstruction in policewoman work. Gender Equality Educ. Q., 6: 42-44.

Chiang, J.P., 1994. A rethinking of the role of in-service police women. Police Sci. Q., 24: 147-180.

Chiang, J.P., 2007. The puzzle and challenges of development of policewoman policy. Police Torch Mag., 609: 28-32.

Lin, L.S., 2013. Feminism and Gender Relations. 4th Edn., Wu Nan Culture Enterprise, Taipei, ISBN-10: 9789571169583, pp: 463.

Sandel, M.J., 2011. Justice what is The Right Thing To Do?

Weng, T.F., 2007. Gender equality in the police. Police Torch Mag., 613: 82-85.

Yeh, Y.L., 2003. The past, present and future policewoman policy. Forum Women's Gender Stud., 68: 49-56.

Yeh, Y.L., 2004. The retrospect and prospect of policewoman policy. J. Central Police Univ., 41: 107-132.

Young, W.P., 2006. Women striving in the masculine workplace: A study on the career path of female police officers in Taiwan. Thesis, Graduate Institute of Social Transformation Studies, Shi Hsin University. 